\title{
Phytosomes: An Advanced Herbal Drug Delivery System
}

\author{
Archana Dhyani* and Divya Juyal \\ Department of Pharmaceutics, Himalyan Institute of Pharmacy and Research, India
}

Submission: April 21, 2017; Published: April 28, 2017

"Corresponding author: Archana Dhyani, Department of Pharmaceutics, Himalyan Institute of Pharmacy And Research, Dehradun, India, Tel: +919456315495; Email: archana.dhyani89@gmail.com

\section{Mini Review}

The word-phyto/herb refers to plants while -some means cell like. Herbosomes are lipid compatible molecular complex. It is a fresh approach to drug delivery system which addresses the limitations of the conventional drug delivery systems. Phytosomes contain the bioactive phytoconstituents of herb extract bounded by lipids. Phytosomes are developed by incorporating standardized plant extract or water soluble bioactive plant constituent into phospholipids to make lipid compatible molecular complex called phytosomes and so progress their absorption and bioavailability. Phytosome method produce a cell which is a expensive component of herbal extract which protected from damage by digestive secretion and gut microbes [1].

\section{Advantages of phytosomes [2]}

As compare to conventional herbal formulation, Phytosomes have following advantages:

I. It enhance the absorption of lipid insoluble polar phytoconstituents through oral as well as topical way showing improved bioavailability, therefore extensively better therapeutic profit.

II. When the absorption of active constituent(s) is enhanced, its quantity requirement is too reduced.

III. Chemical bonds are created between phosphatidylcholine molecule and phytoconstituent, consequently the phytosomes prove improved stability outline.

IV. Additional nutritional profit of phospholipids.

V. Considerable drug entrapment.

VI. Application of phytoconstituents in form of phytosome improves their percutaneous absorption and act as functional cosmetics.
VII. Phytosome process produces a little cell whereby the costly components of the herbal extract are sheltered from damage by digestive secretions and gut bacteria.

\section{Comparison of liposomes and phytosome}

Like to phytosomes, aliposome is a combination of hydrophilic material and phosphatidylcholine in a specific ratio, with a water soluble substance is bounded by phosphatidylcholine molecule. In comparison, phytosomes is a combination of water soluble entity and phosphatidylcholine produced in the ratio of 1:1 or 2:1 molecular complex with chemical bonding between phytoconstituents and phosphatidylcholine. Phytosome have proved to be efficient in topical and skin care products than liposomes [3].

\section{Applications [4]}

I. Phytosome are use in the handling of liver disease include alcoholic hepatic steatosis, drug induced liver damage and hepatitis.

II. Phytosomes are use in anti-inflammatory action, pharmaceutical and in beauty composition.

III. Phytosomes are used to treat acute and chronic liver disease of toxic metabolic or infective source or of degenerative environment.

IV. Phytosomes are used as brain stimulant, immunomodulator ,skin improver, antiwrinkle, anti-aging etc.

V. They are used as anticancer and antioxidant, eg- grape seed.

VI. They are used in hyperlipidemia, vein and skin disorder.

VII. They are used as cancer chemo preventive agent and use to care of benign prostate hyperplasia.

VIII. They are also used to treat hypertension. 


\section{References}

1. Nagasamy, Sumanraj KS, Sai Charitha CH, Karri T (2014) PhytosomesA Review. International Journal of Pharma Sciences 4(4): 622-625.

2. Patil MS, Patil SB, Chittam KP, Wagh RD (2012) Phytosomes: Nove Approach In Herbal Medicines. Asian Journal of Pharmaceutical Sciences And Research 2(3): 1-9.

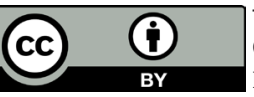

This work is licensed under Creative Commons Attribution 4.0 License DOI: $10.19080 /$ CTBEB.2017.03.555621
3. Salome A, Ikechukwu V Onyishi (2013) Lipid-based drug delivery systems (LDDS): Recent advances and applications of lipids in drug delivery, African Journal of Pharmacy and Pharmacology 7(48): 30343059.

4. Dewan N, Dasgupta D, Pandit S, Ahmed P (2016) Review onHerbosomes, A New Arena For Drug Delivery. Journal of Pharmacognosy and Phytochemistry 5(4): 104-108.

\section{Your next submission with Juniper Publishers will reach you the below assets}

- Quality Editorial service

- Swift Peer Review

- Reprints availability

- E-prints Service

- Manuscript Podcast for convenient understanding

- Global attainment for your research

- Manuscript accessibility in different formats

( Pdf, E-pub, Full Text, Audio)

- Unceasing customer service

Track the below URL for one-step submission https://juniperpublishers.com/online-submission.php 